\title{
ROZWÓJ LOKALNY KIEROWANY PRZEZ SPOŁECZNOŚĆ A JAKOŚĆ ŻYCIA NA OBSZARACH WIEJSKICH WOBEC KONCEPCJI ZRÓWNOWAŻONEGO ROZWOJU
}

\section{COMMUNITY LED LOCAL DEVELOPMENT (CLLD) AND LIFE QUALITY IN RURAL AREAS REGARDING THE CONCEPT OF SUSTAINABLE DEVELOPMENT}

\section{Monika ZADROŻNIAK}

Uniwersytet Łódzki

Wydział Ekonomiczno-Socjologiczny, Katedra Gospodarki Regionalnej i Środowiska

ul. Rewolucji 1905 r. 39, 90-214 Łódź

zarycta@wp.pl

Zarys treści: Artykuł stanowi próbę analizy nowego podejścia do rozwoju obszarów wiejskich, którego jak dotychczas jednym z najistotniejszych celów jest poprawa jakości życia mieszkańców. Realizacja tego podejścia skupia się wokół społeczności lokalnych, które należy traktować jako świadomy podmiot rozwoju, wobec którego koncepcja zrównoważonego rozwoju wyraźnie nakreśla podstawowe założenia i definicję jakości życia, zarówno w podejściu obiektywnym, jak i subiektywnym. Wyniki analizy mogą znaleźć praktyczne zastosowanie w Rozwoju Lokalnym Kierowanym przez Społeczność (RLKS) na obszarach wiejskich.

Słowa kluczowe: obszary wiejskie, zrównoważony rozwój, jakość życia, rozwój lokalny kierowany przez społeczność.

\section{Wstęp}

Mieszkańcy wsi i rolnicy, jak wskazuje B. Fedyszak-Radziejowska (2014, s. 153-174), to „społeczności, których tożsamość, tradycja, historyczne doświadczenia, styl życia oraz sytuacja ekonomiczna, ulegały stereotypizacji w większym stopniu niż innych grup społeczno-ekonomicznych". Tym bardziej akcesja Polski do UE spotęgowała stereotypy, zwłaszcza te dochodowe ${ }^{1}$, mając na uwadze „potężne pieniądze spływające” na wieś w ramach Programu Rozwoju Obszarów Wiejskich.

Jak wskazuje E. Puchnarewicz (2013, s. 245) wieś postrzegana jest jako „miejsce identyfikacji z tradycją, kulturą ludową, zachowaniem ponadczasowych wartości poprzez

1 Według badań CBOS (2013) polskie społeczeństwo przypisywało rolnikom w 2013 r. dochody rzędu 3358,45 zł, podczas gdy w rzeczywistości osobisty, miesięczny dochód netto rolników w tym roku wyniósł 1442 zł. (Czapiński 2013, s.193-194). 
zasiedzenie oraz trwanie niezmiennych dla danego regionu form architektonicznych obiektów sakralnych i świeckich; sposobów gospodarowania, obyczajów związanych z życiem codziennym i świętowaniem". Jednocześnie w polskich warunkach za wiejską uchodzi „szachownica lub pasy pól, panorama z wieżą kościelną, samotna zagroda czy drewniana chata kryta strzechą. Stały się one, podobnie jak sady, symbolem łączności międzypokoleniowej i trwałego zakorzenienia ludzi na danym terytorium. Taka wiejskość, wytwarzana głównie przez miasto i na jego potrzeby, akcentuje »zamrożenie« kultury wsi, jej głębokie zakotwiczenie w tradycji i zakonserwowanie struktur przestrzennych i społecznych" (Górka 2011, s. 250). Jednocześnie wiejskie strefy podmiejskie tracą swój tradycyjny charakter na rzecz tzw. „krajobrazu konsumpcyjnego” (consumption landskape), tworząc połączenia na linii miasto-wieś na bazie turystyki i rekreacji (Heffner i Klemens 2012, s. 82). Należy jednak przyznać, iż obszary wiejskie przechodzą obecnie renesans swojego funkcjonowania w strukturze społeczno-gospodarczej całego kraju, stanowiąc niejako alternatywę dla miasta, tj. dobre miejsce do życia, m.in. z powodu dostępu do bogactwa przyrodniczego². Następuje powrót do tradycji i lokalności traktowanej jako „powrót do utraconego raju” (Iskierski 1987, s. 2-4).

Współcześnie koncepcje rozwoju obszarów wiejskich niezwykle mocno akcentują kwestię poprawy warunków materialnych mieszkańców, a z drugiej strony respektowanie prawa do ochrony zasobów przyrodniczych. Do pogodzenia tych elementów na drodze równoważenia dochodzić może w miejscu cechującym się specyfiką i odgórnie przypisanymi uwarunkowaniami wewnętrznymi i zewnętrznymi, określonymi nie tylko przez granice administracyjne, ale i czas - z racji ciągłości procesu rozwoju, jego trwałości i samopodtrzymywania (Zarychta 2010, s. 201). J. Kołodziejski (1999, s. 63) wskazuje następujące elementy procedury równoważenia rozwoju w przestrzeni:

1) społeczna zasadność (akceptacja) - pole ładu społecznego,

2) ekonomiczna efektywność - pole ładu ekonomicznego,

3) ekologiczna racjonalność - pole ładu ekologicznego.

Dlatego też punktem wyjścia rozważań na temat przyszłości rozwoju obszarów wiejskich staje się koncepcja zrównoważonego rozwoju, w której znaczenia nabiera antropocentryczna pozycja człowieka jako uprzywilejowanego podmiotu rozwoju ${ }^{3}$. Podmiot ten ma możliwość realizowania swoich celów w powszechnym, społecznym systemie wiejskim, z którego wyłania się społeczeństwo obywatelskie (Balawajder 2007), ale również kształtowania systemu wartości wraz z hierarchią potrzeb, które służą rozwojowi człowieka, a tym samym kształtują wspólnotę społeczną (Kowalczyk 2005, s. 232-240). Współczesna wieś, chociaż inna niż do tej pory, lekko zmanierowana, zelektryfikowana, z szerokim dostępem do mediów, ale jednak skupiona jest wokół określonych w przestrzeni zasobów i możliwości, wartości i tradycji, gdzie poglądy i postawy społeczne względem lokalnych inicjatyw dają pewien obraz rozwoju utożsamianego nie tylko w kategoriach wzrostu gospodarczego, ale i postępu jakościowego. Istnieje zatem głęboka potrzeba świadomości na temat roli własnej aktywności społecznej, poczucia tzw. mocy sprawczej wśród mieszkańców wsi. Można posunąć się do stwierdzenia, iż transformacja

\footnotetext{
2 Zob. także: M. Zadrożniak (2015a, s. 211-218).

3 Umiarkowany antropocentryzm jako system wartości wraz z zintegrowaną odpowiedzialnością mają zapewnić właściwy zakres odpowiedzialności człowieka akcentujący jego nadrzędne miejsce i uwzględniający sprawiedliwość wewnątrz i międzypokoleniową poprzez należyte zachowanie wartości środowiska przyrodniczego (w opozycji do skrajnego egocentryzmu i braku odpowiedzialności) (Łuszczyk 2013, s. 51).
} 
systemowa zapoczątkowała zmiany, była ich zarzewiem, ale dziś to „pieniądz”, użyty świadomie na rzecz rozwoju kierowanego przez lokalne aktywności, może uskutecznić zapoczątkowany proces równoważenia rozwoju dla osiągnięcia optymalnej, społecznie akceptowalnej jakości życia.

\section{Jakość życia jako cel kształtowania zrównoważonego rozwoju obszarów wiejskich}

Rozwój jest kategorią silnie związaną z systemem wartości (tj. zbiorem kryteriów i zasad, przez które obserwowany jest proces zmian). Wśród podstaw formułowania nowych celów rozwoju obszarów wiejskich funkcjonować powinno prawo regionu wg S. Kozłowskiego (2002): „rozwój musi uwzględniać regionalne i lokalne uwarunkowania bądź współczesne podejście do bioregionalizmu"4.

Zrównoważony rozwój obecnie interpretuje się dość szeroko jako (Trzepacz 2012, s. 18 za Adamowicz 2006, s. 11-25):

- ideę społeczno-filozoficzną (zakładającą potrzebę zmian w systemie wartości człowieka),

- nowoczesny kierunek rozwoju gospodarczego, zakładający nowe sposoby organizowania i zarządzania gospodarką,

- nowo powstającą dyscyplinę naukową.

Koncepcja zrównoważonego rozwoju stanowi odpowiedź na problemy współczesnego świata, rozpatruje się ją w kategoriach kompromisu między bardziej „mieć” czy bardziej „być”? Zwraca uwagę na wpływ środowiska przyrodniczego na jakość życia bezpośrednio, jak i poprzez wpływ na funkcjonowanie systemów gospodarczych i społecznych, stanowiąc niejako warunek konieczny dla tego rozwoju. „(...) Trwały i zrównoważony rozwój jest zatem kwestią wyborów - z czego można zrezygnować, a z czego nie" (Dobrzański i Dobrzańska, 2010, s. 258-259).

Historia kształtowania się koncepcji, różny sposób jej postrzegania i interpretowania sprawia, że współczesny jej odbiór nie jest jednoznaczny. Rozwój zrównoważony, w dużej mierze powiązany z poprawą jakości życia w kategoriach sprawiedliwości wewnątrz i międzypokoleniowej oraz formułowania celów długoterminowych ${ }^{5}$, definiuje się jako: „rozwój zapewniający zaspokojenie potrzeb współczesnych i przyszłych pokoleń" (Tyburski 2011, s. 9-10). Wśród głównych celów zrównoważonego rozwoju wskazuje się poprawę jakości życia posiadającą wiele interpretacji, najczęściej traktowaną jako „zbiór czynników określających obiektywne warunki życia i subiektywnie odczuwany dobrobyt" (Glatzer 2006, s. 12). T. Borys (2005, s. 25) z kolei zapewnia jakości życia miejsce w tzw. „wielkiej trójce", pod warunkiem zgodności systemów wartości, tj.:

- określonej koncepcji jakości życia,

- określonej koncepcji rozwoju społeczno-gospodarczego,

${ }^{4}$ Strategia bioregionalizmu opiera się na:

- stabilnej gospodarce zapewniającej odpowiednią, jakość życia,

- racjonalnej i skutecznej ochronie środowiska,

- uznaniu roli i rangi bioregionów w rozwoju społeczeństw,

- edukacji w celu wypracowania tożsamości bioregionalnej (Kiryluk 2009, s. 40).

${ }^{5}$ Św. Jan Pawełll upatrywał rozwiązania problemu nierówności społeczno-ekonomicznych w zrównoważonym rozwoju, traktując priorytetowo kierunek "wyrównywania oraz szukania dróg sprawiedliwego rozwoju dla wszystkich" (Encyklika 1981, s. 106-107). 
- określonej koncepcji instrumentarium6

Należy jednocześnie mocno zaznaczyć kwestię zasadniczą, jaką jest ustalenie hierarchii potrzeb determinujących jakość życia jednostki, zbiorowości w danym miejscu (regionie) i czasie. Decydujące znaczenie ma subiektywne i obiektywne postrzeganie jakości życia jako celu, kategorii czy podstawy koncepcji zrównoważonego rozwoju. Z perspektywy obszarów wiejskich należy podkreślić, iż sam dostęp do dóbr i usług nie stanowi jeszcze o wysokiej jakości życia mieszkańców, stąd przytoczone w pracy M. Łuszczka (2013, s. 156-157) badania W. Zapfa na temat tzw. „paradoksu zadowolenia", traktowanego jako stan akceptacji subiektywnie dobrego samopoczucia przy obiektywnie złych warunkach życia.

Jakość życia jako kategoria wielowymiarowa budzi obecnie zainteresowanie szeregu nauk: ekonomii, socjologii, psychologii, etyki czy filozofii. M.in. T. Borys i P. Rogala $(2008)^{7}$, M. Łuszczyk (2013), M. Leźnicki (2011) czy E. Rokicka (2013)8 prezentują szeroki przegląd definicji jakości życia, przedstawiając kontrowersje dotyczące samej terminologii, mając szczególnie na uwadze współczesne potrzeby dotyczące konstruowania wskaźników, a wreszcie pomiaru jakości życia. Wydaje się bowiem, iż obecnie potwierdza się nieadekwatność PKB w ocenie jakości życia, której wysoką wartość można budować niezależnie od ilościowego wzrostu gospodarczego czy też postępu technicznego (Łuszczyk 2013). Jakość życia „wyraża stopień samorealizacji człowieka w ujęciu holistycznym (przy równowadze dobrobytu, dobrostanu i błogostanu) lub w ujęciu mniej czy bardziej zawężonym, np. z punktu widzenia konsumpcji dóbr materialnych zaspokajających jego

${ }^{6}$ RKLS jako narzędzie realizacji koncepcji zrównoważonego rozwoju obszarów wiejskich w warunkach lokalnych, kształtujące tym samym wysoką jakość życia mieszkańców.

7 Autorzy proponują kryteria, na podstawie których prezentują 7 klasyfikacji jakości życia (2008, s. 10-16):

1) wartościująca (oceniająca, preferencyjna): pozytywna, negatywna i niewartościująca (opisowa): określenie odrębności i podobieństwa;

2) globalna (pełne pole obserwacji): sfera fizyczna, psychiczna i duchowa wraz z poziomami potrzeb człowieka i ograniczona (fragmentaryczne pola obserwacji): sferowanie jakości życia m.in. wg 6 sfer Kolmana, 13 sfer Campbella (Borys 2004, s. 9);

3) subiektywna (ocena stopnia zaspokojenia potrzeb) i obiektywna (znaczeniowo zbliżona do warunków życia lub poziomu życia) (Czapiński 2007, s. 13);

4) indywidualna (poszczególnych sfer życia jednostki w ujęciu subiektywnym i obiektywnym) i zbiorowa (uogólnienia indywidualnych jakości życia);

5) bezpośrednia (pochodząca z bezpośrednich badań) i pośrednia (pośrednie wskaźniki jakości życia);

6) zrównoważona i niezrównoważona:

- 2-modułowe: równoważenie między jakością typu „mieć” (having) i jakością typu „być” (being),

- 3-modułowe: równoważenie między jakością typu “mieć” (having), „być” (being), "kochać” (loving).

Zrównoważona jakość życia oznacza zrównoważone docenianie i dostrzeganie całego bogactwa globalnej jakości i współistnienia w życiu człowieka zarówno cech jakości typu „mieć”, typu „być”, jak i typu „kochać”, czyli równoważenia rozwoju fizycznego, psychicznego i duchowego (uczuciowego);

7) aksjologiczna, (związana z systemem wartości), wymienia się m.in.: antropocentryczna, egocentryczna, patocentryczna, biocentryczna, holistyczna.

8 E. Rokicka (2013, s. 161) wyróżnia 5 głównych nurtów zainteresowań nad jakością życia:

1) skupiający się na ochronie środowiska naturalnego (wskazuje konsekwencje postępu cywilizacji dla środowiska naturalnego, zdrowia i jakości życia człowieka w związku z hałasem, zanieczyszczeniem wód czy powietrza itp.);

2) związany z pomiarem zdrowia (w naukach medycznych jakość życia uwarunkowana stanem zdrowia);

3) odnoszący się do procesów urbanizacji (niekorzystne skutki rozwoju naukowo-technicznego na obszarach zurbanizowanych, m.in.: wadliwe planowanie miast, mieszkań itp.);

4) oparty na motywach społeczno-psychologicznych (negatywne konsekwencje rozwoju cywilizacyjnego dla jednostki i życia społecznego, m.in.: samoalienacja, wyobcowanie społeczne, osamotnienie itp.);

5) koncentrujący się na ekonomicznym aspekcie jakości życia (jakość życia jednostki, społeczności lokalnej, regionalnej i kraju, traktowana jako zmienna wyjaśniana jak i wyjaśniająca).

We wszystkich wymienionych nurtach, jak wskazuje E. Rokicka obecna jest zarówno komparatywna (wartościująca), jak i deskryptywna (niewartościująca) orientacja w ujmowaniu jakości życia. 
potrzeby (przy dominacji dobrobytu nad dobrostanem i błogostanem) " (Borys i Rogala 2008, s. 9).

Według B. Kasprzyk (2013, s. 17) ekonomia dobrobytu (welfare economics) stała się współcześnie podstawą dobrobytu i dobrostanu ogólnego, obejmującego tzw. well being, quality of life, tj. pozamaterialne czynniki egzystencji człowieka ${ }^{9}$. Autorka definiuje współczesne rozumienie dobrobytu jednostki na podstawie E. Aksman (2010, s. 143) jako „poziom realnego dochodu, majątku = ogólny dostatek ekonomiczny oraz poczucie bezpieczeństwa ekonomiczno-społecznego, które wyraża się poprzez: pewność zatrudnienia, stabilność cen, zapewnienie ochrony zdrowia, zabezpieczenie społeczne, poziom wiedzy i wykształcenia, styl życia przesądzający o jakości życia, a także komponenty związane z funkcjonowaniem społecznym, politycznym, obywatelskim, rodzinnym (np. pozycja zawodowo-społeczna, korzystanie ze swobód obywatelskich, posiadanie rodziny, poczucie własnej wartości w życiu itd.) ".

Rozpatrywanie jakości życia przez pryzmat koncepcji zrównoważonego rozwoju sprowadza się w aspekcie praktycznym m.in. do ujęcia wskaźnikowego. Jak zauważają T. Borys i P. Rogala (2008, s. 67): „wskaźniki zrównoważonego rozwoju, takie jak np. urodzenia żywe na 1000 mieszkańców, liczba lekarzy na 1000 mieszkańców czy liczba mieszkań na 1000 mieszkańców to także pośrednie wskaźniki jakości życia. Tego typu pomiar jakości życia (np. w gminach) jest więc jednocześnie pomiarem zrównoważonego rozwoju".

Jakość życia w kontekście koncepcji zrównoważonego rozwoju to zatem ogół warunków życia jednostki/grupy kształtujących się w wymiarach społecznym, gospodarczym, środowiskowym i świadomościowym rozwoju określonej przestrzeni, które w ujęciu obiektywnym i subiektywnym stanowią o naszym poczuciu zaspokojenia potrzeb i spełnienia aspiracji życiowych w danym miejscu i czasie ${ }^{10}$. Tak sformułowana jakość życia w myśl idei zrównoważonego rozwoju formułuje wizję rozwoju wiejskich społeczności lokalnych ${ }^{11}$. Jakość życia określa również miejsce środowiska przyrodniczego, odwołując się do teorii bioregionalizmu i antropocentryzmu, wreszcie w odniesieniu do subiektywnej i obiektywnej oceny jakości życia ${ }^{12}$. Pytanie: bardziej „mieć” czy bardziej „być”? - określające jakość życia, poszerzone o „być w środowisku”, „uczestniczyć w jego ograniczonych zasobach” - wyznacza współczesne trendy rozwojowe i określa możliwości wdrażania zrównoważonego rozwoju (Leźnicki 2011, s. 228-231). Współcześnie mówi się także o filozofii jakości życia oraz tzw. filozofii zrównoważonego rozwoju ${ }^{13}$. Istotę problemu odzwierciedla pytanie: „która jakość życia - oparta na jakim systemie wartości - najlepiej wpisuje się w ideę zrównoważonego rozwoju i jest wierna jego istocie?" (Tyburski 2011, s. 29).

${ }^{9}$ E. Rokicka (2013, s. 162) utożsamia obiektywny wymiar jakości życia z dobrobytem (welfare), natomiast subiektywny (well-being) z dobrostanem.

10 W odniesieniu do obszarów wiejskich znaczenia nabiera prezentowane w modelu Kaptayna, van Praaga i van Herwaardena podejście, uwzględniające istotne charakterystyki społeczne dla każdej indywidualnej jednostki, takie jak: wykształcenie, sektor zatrudnienia, typ pracy, stopień urbanizacji, wiek i miejsce zamieszkania. Proces, „kto patrzy na kogo” w kategoriach grupy odniesienia - jednostki zwracają uwagę na dochody osób o podobnym bądź wyższym wykształceniu, podobnym wieku (Kasprzyk 2013, s.102, za: Pragg i in.1979).

11 Analiza SWOT obszarów wiejskich w kontekście poprawy jakości życia mieszkańców (Zadrożniak 2015b).

12 Wg A. Kalety (1985, s. 10-11) jest to kategoria podwójnie subiektywna po pierwsze ze względu na subiektywne uznanie pewnych potrzeb za wartości egzystencjalne a po drugie indywidualną ocenę stopnia ich zaspokojenia.

${ }^{13}$ Wg Z. Hulla (2011, s. 33-81) interpretacja jakości życia pozostaje w związku z określonymi zadaniami koncepcji zrównoważonego rozwoju. 


\section{Rozwój Lokalny Kierowany przez Społeczność (RLKS) - szansa na realną poprawę jakości życia mieszkańców obszarów wiejskich w myśl koncepcji zrównoważonego rozwoju}

Rozwój obszarów wiejskich ma być rozwojem lokalnym kierowanym przez społeczność, który respektuje i wypływa z założeń koncepcji zrównoważonego rozwoju, wskazując w warunkach wiejskich priorytety, szczególnie istotne dla władz samorządowych i lokalnych liderów społecznych i gospodarczych. A. Pawłowski (2007) źródłom słabości koncepcji zrównoważonego rozwoju przypisuje koncentrację na dalekosiężnych planach przy jednoczesnym lekceważeniu problemów czasu obecnego (zwłaszcza innych niż środowiskowe), z drugiej jednak strony zrównoważony rozwój jest uznawany za „bezpośredni rezultat tego stylu zarządzania, który określany jest mianem współrządzenia i współpracy różnych podmiotów" (Adamski i in. 2007, s. 79). W tym kontekście, cytując B. M. Dobrzańską (2009, s. 20-27), znaczenia nabiera zasada partycypacji, ze względu na fakt, iż:

- rozwój (w tym obszarów cennych przyrodniczo) dotyczy ekologicznych, społeczno-kulturowych, ekonomicznych, instytucjonalnych i przestrzennych uwarunkowań zaspokajania potrzeb ludzi - społeczeństwo musi mieć możliwość ich wyartykułowania i wpływ na ich uwzględnienie w planach rozwoju;

- zrównoważony rozwój jest w znacznej mierze koncepcją normatywną, a w świecie wolności obywatelskich arbitralne narzucanie koncepcji rozwoju opartego na określonych wartościach nie powinno mieć miejsca;

- różnorodność interesów indywidualnych bądź grupowych powoduje, że nie istnieją uniwersalne kryteria oceny zróżnicowania rozwoju - niezbędne są więc procedury pozwalające poznać partykularne kryteria i doprowadzić do przejrzystych decyzji odnośnie trade-off i kompromisów.

Teoretyczne rozważania nad istotą rozwoju zrównoważonego obszarów wiejskich dla władz lokalnych czy lokalnych grup działania sprowadzają się do wzrostu poziomu świadomości mieszkańców na temat funkcjonowania pojęcia zrównoważonego rozwoju w kreowaniu lokalnych potrzeb, skupiają się wokół trudności w definiowaniu wzajemnych relacji na linii zrównoważony rozwój - jakość życia, a w konsekwencji ich wzmocnienia bądź osłabienia.

Rozwój Lokalny Kierowany przez Społeczność (RLKS) - Community Led Local Development (CLLD) - to nowy instrument terytorialny wprowadzony przez Komisję Europejską do realizacji w perspektywie finansowej na lata 2014-202014. Instrument ten bazuje na stosowanym w latach 2007-2013, w ramach Wspólnej Polityki Rolnej (WPR) i Wspólnej Polityki Rybołówstwa (WPRyby), podejściu LEADER i zachowuje jego podstawowe założenia ${ }^{15}$.

14 Zob. także dokument Wspólne wytyczne Dyrekcji Generalnych Komisji Europejskiej, Agri, Empl, Mare i Regio, na temat rozwoju kierowanego przez lokalną społeczność w ramach europejskich funduszy strukturalnych i inwestycyjnych. Wersja robocza, 30.01.2013. Szczególnie istotne znajduje się tu pytanie o określenie wyzwań i celów, geografię efektywnego rozwoju lokalnego oraz Jak pracować razem?, s. 17-19.

15 Są to (Zasady... 2014, s. 3):

a) oddolność (szeroki udział społeczności lokalnej w tworzeniu i realizacji strategii),

b) terytorialność (lokalna strategia rozwoju przygotowana dla danego, spójnego obszaru),

c) zintegrowanie (łączenie różnych dziedzin gospodarki, współpraca różnych grup interesu),

d) partnerstwo (lokalna grupa działania jako lokalne partnerstwo, w którym uczestniczą różne podmioty z sektora publicznego, społecznego i gospodarczego),

e) innowacyjność (w skali lokalnej),

f) decentralizacja zarządzania i finansowania,

g) sieciowanie i współpraca (wymiana doświadczeń i rozpowszechnianie dobrych praktyk). 
RLKS - zgodnie z przepisami rozporządzenia ramowego - jest (Zasady... 2014, s. 3):

1) skoncentrowany na konkretnych obszarach poniżej szczebla regionalnego;

2) kierowany przez lokalne grupy działania (LGD), w których skład wchodzą przedstawiciele władz publicznych, lokalnych partnerów społecznych i gospodarczych oraz mieszkańców, przy czym na poziomie podejmowania decyzji ani władze publiczne - określone zgodnie z przepisami krajowymi - ani żadna z grup interesu nie posiada więcej niż 49\% praw głosu;

3) prowadzony na podstawie zintegrowanych i wielosektorowych lokalnych strategii rozwoju;

4) zaprojektowany z uwzględnieniem lokalnych potrzeb i potencjału oraz zawiera elementy innowacyjne w kontekście lokalnym i zakłada tworzenie sieci kontaktów oraz, w stosownych przypadkach, współpracę.

Zdaniem I. Nurzyńskiej (2014, s. 38-39), na uwagę zasługuje nazwa podejścia Community Led Local Development ${ }^{16}$, która oddaje rolę lokalnej społeczności (led local) w kreowaniu i stymulowaniu rozwoju. Szczególne znaczenie z punktu widzenia dotychczasowych rozważań ma wspomniana partycypacyjność w RLKS, która powinna wykształcać w społecznościach i lokalnych samorządach umiejętności porozumiewania się, wyrażania swoich opinii, ale i wzmacniać poczucie współodpowiedzialności za swój własny rozwój (Zasady... 2014, s. 17-18).

P. Chelavier i M.C. Maurel (2010, s. 29) zaznaczają, że podejście LEADER w nowych krajach członkowskich UE przyjmuje się poprzez tzw. „przyjęcie uzależnione od postaw lokalnych interesariuszy. To oni finalnie decydują o realizacji nowego modelu polityki rozwoju wsi. Efektywność realizacji zależy zatem od zaangażowania władz lokalnych, odpowiedzialnych za rozpowszechnianie informacji wśród reprezentantów innych sektorów. (...) Na ogólny klimat zniechęcenia wójtów i radnych do tworzenia LGD wpływa obciążenie budżetu gmin finansowaniem inwestycji z PROW. W ich świadomości tworzenie takiej organizacji wymaga nakładów finansowych i nie jest możliwe na zasadzie non-profit czy pospolitego ruszenia".

Słowem kluczem, stanowiącym podstawę sukcesu realizacji podejścia RLKS, jest zatem partycypacja społeczna, a raczej lokalna, definiowana jako „udział obywateli w zarządzaniu sprawami społeczności, której są członkami” (Hausner 1999, s. 41), zwracając szczególną uwagę na rolę podmiotowości ${ }^{17}$ człowieka w zrównoważonym rozwoju obszarów wiejskich. Samo oczekiwanie na pomoc z zewnątrz prowadzi nieuchronnie do przypadkowych, nieskoordynowanych działań, zaprzeczających postulatom sampodtrzymywania trwałej poprawy jakości życia (szczególnie w wymiarze społecznym, świadomościowym zrównoważonego rozwoju), a z drugiej strony zamyka społeczności lokalne we własnym środowisku, utrwalając tym samym postawy bierności. Jak wskazuje J. Iskierski (1987, s. 3), nie sposób mówić o społecznościach lokalnych (systemy zorganizowanych działań) i świadomości lokalnej (świadomość wspólnych interesów czy szerzej jako podmiotowość lokalna), traktując je z góry, z zewnątrz. Wewnętrzna siła rozwoju obszarów wiejskich wobec podstawowych koncepcji rozwoju

${ }^{16}$ Zob. także dokument Wspólne wytyczne Dyrekcji Generalnych Komisji Europejskiej, Agri, Empl, Mare i Regio, na temat rozwoju kierowanego przez lokalną społeczność w ramach europejskich funduszy strukturalnych i inwestycyjnych. Wersja robocza - 30.01.2013. Szczególnie istotne znajduje się tu pytanie o określenie wyzwań i celów, geografię efektywnego rozwoju lokalnego oraz Jak pracować razem? (s. 17-19).

17 Zob. P. Sztompka (2005, s. 531). 
lokalnego nawiązuje do wykorzystania wewnętrznych lokalnych zasobów dla podniesienia poziomu życia czy tworzenia instytucji rozwoju lokalnego, a jednocześnie są one „otwarte dla każdego" (Parysek 2001, s. 175-176).

Społecznością idealną byłaby według M. Klekotko (2008, s. 27) społeczność zaangażowana w pełni zarówno w instytucjonalne formy aktywności obywatelskiej, jak i nieformalnej, orientująca się w sprawach kraju i swojego lokalnego środowiska, biorąca udział w życiu politycznym. Idealne byłoby zatem tworzenie w ramach partycypacji społecznej określonego systemu współrządzenia (governance), opartego na realnie niehierarchicznych powiązaniach sektorów: społecznego, publicznego i gospodarczego. Według M. Furmańczyka (2013) demokracja partycypacyjna tworzy formy organizacyjne regional governance, tzw. partnerstwa terytorialne, w tym LGD. Jak zauważa autor, w tej idealistycznej wersji governance „znaczący wpływ na decyzję o alokacji środków (poprzez wybór celów strategii i projektów lokalnych do realizacji) powinny mieć (oprócz władz publicznych) społeczności lokalne zorganizowane w sektorze pozarządowym i przedsiębiorcy, a więc podmioty spoza hierarchicznego sektora administracji publicznej". Jednocześnie interesy przedstawicieli wyżej wymienionych sektorów powinny się równoważyć oraz zmuszać do kompromisów i negocjacji, co stanowi gwarant stałej kontroli finansowej wydatków publicznych i zabezpieczenia zaspokojenia różnych potrzeb, różnych grup społecznych (Furmańczyk 2013, s. 72-74). Idea współrządzenia w społeczności lokalnej, zdaniem K. Zajdy i A. Kretek-Kamińskiej (2014, s. 111), opiera się na „tworzeniu sieci współdziałających ze sobą w oparciu o wzajemne zaufanie i dla dobra wspólnego podmiotów, reprezentujących możliwie liczne i różne kategorie aktorów, funkcjonujących w tej społeczności".

Istotne z punktu widzenia tworzenia rzeczywistych partnerstw, opartych na zasadach równego dostępu w myśl RLKS, stają się zatem następujące kwestie:

- struktura władzy rad decyzyjnych LGD, „ukryta” liczba członków z władz publicznych; władza lokalna często nie dysponuje wyczerpującymi informacjami na temat szeregu kwestii, o których musi decydować, a o których wiedza znajduje się w posiadaniu lokalnych aktywistów, działaczy, itp. (Zajda i Kretek-Kamińska, 2014, s. 109);

- procedury administracyjne dokonujące wyborów projektów do dofinansowania i realizacji; tzw. „kolonizacja partnerstw” przez aparat biurokracji samorządowej (Knieć 2011, s. 166-168);

- promocja polityczna władzy lokalnej płynąca z decyzyjności w radach LGD;

- wpływ partnerstw na budowanie i wzmacnianie kapitału społecznego, społeczeństwa obywatelskiego, kreując nowych liderów, wzmacniając i odbudowując tożsamość lokalną, tworząc płaszczyznę integracji społeczności lokalnych, wymiany doświadczeń i dostępności wiedzy (Knieć 2011, s. 170-172).

\section{Podsumowanie}

Doświadczenia z poprzedniej perspektywy finansowej 2007-2013 dały już wstępne wnioski na temat kwestii partycypacji i zaangażowania społeczności lokalnych w rozwój obszarów wiejskich. K. Zajda (2012, s. 69-81) wśród przyczyn niedostosowania podejścia LEADER w gminach wiejskich województwa łódzkiego wskazuje niski poziom wiedzy elit władzy i biznesu, liderów lokalnych oraz niewielki potencjał sektora NGO. 
Należy publicznie przyznać, że polska wieś w dalszym ciągu potrzebuje wsparcia. Dopłaty bezpośrednie nie wyrównują, wbrew mylnym przekonaniom, wszystkich zapóźnień społeczno-gospodarczych. Jednocześnie ważne, aby nie był to argument dla tworzenia tzw. „towarzystwa wzajemnej adoracji” w praktycznym ujęciu i realizacji działalności LGD.

O koncepcji zrównoważonego rozwoju, jak i pojęciu jakości życia mówimy w kategoriach systemu norm i wartości, tradycji i kultury, hierarchii potrzeb, które tworzą obraz subiektywnego poczucia szczęścia mieszkańców obszarów wiejskich. Zatem nie należy tej sfery lekceważyć także w podejściu RLKS. Uświadomienie sobie miękkich, społecznych kategorii stanowi pewien punkt wyjścia dla twardych, obiektywnych wskaźników związanych z inwestycjami infrastrukturalnymi.

Założenie oddolności jest równoznaczne z partycypacyjnością i należy w myśl koncepcji zrównoważonego rozwoju stawiać człowieka w centrum rozwoju, ze wszystkimi jego przywilejami i obowiązkami.

Istotą zrównoważonego rozwoju obszarów wiejskich jest zwrócenie uwagi na wyczerpywanie się zasobów środowiska przyrodniczego w ujęciu lokalnym - to najistotniejszy element warunkujący rozwój zrównoważony w sensie terytorialnym i przestrzennym. Jego istotność należy traktować na równi z celami społecznymi i gospodarczymi, jako że poprawa jakości życia mieszkańców wiąże się współcześnie z poprawą oraz utrzymaniem stanu środowiska przyrodniczego.

RLKS musi zapewniać wiedzę i edukację na rzecz zrównoważonego rozwoju, traktując ją na równi z inwestycjami infrastrukturalnymi. Tylko inwestycja w świadomość społeczności lokalnych może przynieść realny, trwały i samopodtrzymujący się zwrot obszarów wiejskich na drogę rozwoju zrównoważonego (mimo pewnych głosów na temat trudności zastosowania koncepcji do całego kraju, a w szczególności do regionu i szczebla lokalnego).

Dalsza realizacja podejścia governance we wdrażaniu podejścia RLKS będzie skuteczna jedynie wobec dążenia do niwelowania dominacji władz publicznych w radach LGD, co stanowić może pewien sposób ograniczania wpływu lokalnych elit zarówno na procedury, jak i ostateczne decyzje. Otwiera to w konsekwencji wolną drogę pozostałym podmiotom o niższej pozycji w strukturze społeczno-gospodarczej regionu, oraz o mniejszej dostępności do wiedzy i programów wsparcia finansowego (Furmańczyk 2013, s. 85). Istotny jest także nacisk na rozwój lokalnej społeczności w kontekście rozwiązywania problemów lokalnych, a nie globalnych czy narodowych (Knieć 2011, s. 172). Podejście lokalne w tym ujęciu oznacza m.in., że LGD rozpatruje tylko te wnioski o wsparcie, których realizacja może wpłynąć na poprawę jakości życia ludności, zamieszkującej dany obszar (Leśniak 2013, s. 11).

Na obszarach wiejskich RLKS „wkłada w ręce” mieszkańców narzędzie do kreowania przestrzeni w ramach trzech wartości: zdrowie, dobrobyt, rodzina (Borys i Rogala, 2008, s. 47). Jednocześnie należy mieć na uwadze fakt, iż obiektywnej poprawie poziomu życia towarzyszy zwiększone poczucie poprawy jakości życia, poczucie zadowolenia, satysfakcji czy szczęścia (Campbell 1976). Decydujące znaczenie odgrywa zatem rola partycypacji społecznej, jakkolwiek odpowiadając na pytanie M. Mularskiej (2008, s. 220), wsi nie można zmienić bez udziału jej mieszkańców. 


\section{Literatura}

Adamowicz M., 2006, Koncepcje trwałego i zrównoważonego rozwoju wobec wsi i rolnictwa, Prace Naukowe Katedry Polityki Agrarnej i Marketingu SGGW, 38, s. 11-25.

Aksman E., 2010, Redystrybucja dochodów i jej wpływ na dobrobyt społeczny w Polsce w latach 1995-2007, Uniwersytet Warszawski, Warszawa.

Balawajder E. (red.), 2007, Społeczeństwo obywatelskie. Modele teoretyczne i praktyka społeczna, KUL, Lublin.

Borys T., 2004, Jakość życia oraz pojęcia i relacje pochodne [w:] Metodologia pomiaru jakości życia, W. Ostasiewicz (red.), Wydawnictwo AE we Wrocławiu, Wrocław 2002, s. 9-12

Borys T. (red.), 2005, Wskaźniki zrównoważonego rozwoju, Wydawnictwo Ekonomia i Środowisko, Warszawa-Białystok.

Borys T., Rogala P., 2008, Jakość życia na poziomie lokalnym - ujęcie wskaźnikowe, Program Narodów Zjednoczonych ds. Rozwoju (UNDP) w Polsce, Warszawa

Campbell A., 1976, Subjective measures of well-being, American Psychologist, 2, s. 117-124.

CBOS, 2013,. Polacy o zarobkach różnych grup zawodowych, Komunikat/BS/127/2013.

Chelavier P., Maurel M.C., 2010, Program Leader w krajach Europy środkowej, Wieś i Rolnictwo, 4 (149), s. 26-41.

Czapiński J., Panek T. (red.), 2007, Diagnoza społeczna. Warunki i jakość życia Polaków, Wyższa Szkoła Finansów i Zarządzania w Warszawie, Warszawa.

Czapiński J., 2013, Indywidualna jakość życia i styl życia, [w:] J. Czapiński, T. Panek (red.), Diagnoza społeczna 2013. Warunki i jakość życia Polaków - raport, Rada Monitoringu Społecznego, Warszawa, s. 172-278.

Dobrzańska B. , 2009, Zasada partycypacji jako przesłanka i podstawa tworzenia wskaźników zrównoważonego rozwoju, [w:] Zrównoważony rozwój - aspekty rozwoju społeczności lokalnych, Fundacja Forum Inicjatyw Rozwojowych, Białystok, s. 20-28.

Dobrzański G., Dobrzańska B. M, 2010, Trwały i zrównoważony rozwój, [w:] B. M. Dobrzańska, G. Dobrzański, D. Kiełczewski (red.), Ochrona środowiska przyrodniczego, Wydawnictwo Naukowe PWN, Warszawa, s. 252-263.

Encyklika Laborem exercens, Św. Jan Paweł II, 1981.

Fedyszak-Radziejowska B., 2014, Społeczności wiejskie w 10 lat po akcesji. Postawy, wartości i uwarunkowania społeczno-ekonomiczne, [w:] I. Nurzyńska, W. Poczta, (red.), Polska wieś 2014. Raport o stanie wsi, Wydawnictwo Scholar, Warszawa, s. 153-174.

Furmańczyk M., 2013, Współrzqdzenie czy ukryta dominacja sektora publicznego? Koncepcja Governance w praktyce Lokalnych Grup Działania Leader, [w:] Studia Regionalne i Lokalne, 1, 51, s. $71-88$.

Glatzer W., 2006, Conditions and Criteria for Improving Quality of Life, [w:] W. Ostasiewicz (red.), Towards Quality of Life Imroviement, The Publishing House of the Wrocław University of Economics, Wrocław, s. 9-32.

Górka A. 2011, Krajobraz kulturowy wsi jako nośnik mitu, [w:] Niematerialne wartości krajobrazów kulturowych, Prace Komisji Krajobrazu Kulturowego PTG, 15, Sosnowiec, s. 248-258.

Hausner J. (red.), 1999, Komunikacja i partycypacja społeczna. Poradnik, Małopolska Szkoła Administracji Publicznej Akademii Ekonomicznej, Kraków.

Heffner K., Klemens B., 2012, Warunki życia i aktywność społeczno-gospodarcza mieszkańców na obszarach wiejskich (na przykładzie województwa opolskiego), Barometr Regionalny, 4 (30), s. $81-88$. 
Hull Z., 2011, Wprowadzenie do filozofii zrównoważonego rozwoju, [w:] W. Tyburski (red.), Zasady kształtowania postaw sprzyjajqcych wdrażaniu zrównoważonego rozwoju, Uniwersytet Mikołaja Kopernika, Toruń, s. 33-81.

Iskierski J., 1987, Lokalność czyli powrót do raju utraconego, Pomerania, 7, wydanie elektroniczne, s. 2-4.

Kaleta A., 1985, Jakość życia mieszkańców wsi rejonu uprzemysłowionego, Rozprawy, Uniwersytet Mikołaja Kopernika, Toruń.

Kasprzyk B., 2013, Wybrane aspekty oceny dobrobytu ekonomicznego i jakości życia (ujęcie regionalne - Podkarpacie), Uniwersytet Rzeszowski, Rzeszów.

Kiryluk A., 2009, Bioróżnorodność i bioregionalizm jako czynniki zrównoważonego rozwoju. Obszarów wiejskich i turystyki w województwie podlaskim, [w:] Zrównoważony rozwój - aspekty rozwoju społeczności lokalnych, Fundacja Forum Inicjatyw Rozwojowych, Białystok, s. 38-47.

Klekotko M., 2008, Społeczeństwo obywatelskie a rozwój zrównoważony wsi. Podejście poznawcze, [w:] H. Podedworna, P. Ruszkowski (red.), Społeczne aspekty zrównoważonego rozwoju wsi w Polsce. Partycypacja lokalna i kapitał społeczny, Wydawnictwo Naukowe SCHOLAR, Warszawa, s. 21-36.

Knieć W., 2011, Partnerstwa lokalne w budowie społeczeństwa obywatelskiego na obszarach wiejskich, [w:] H. Podedworna, A. Pilichowski (red.), Obszary wiejskie w Polsce. Różnorodność i procesy różnicowania, Instytut Filozofii i Socjologii PAN, PTS, Warszawa.

Kołodziejski J. 1999, Strategia równoważenia rozwoju miast polskich w perspektywie integracji przestrzeni europejskiej, [w:] G. Gorzelak, M. S. Szczepański, T. Zarycki (red.), Rozwój-Region - Społeczeństwo,, Europejski Instytut Rozwoju Regionalnego i Lokalnego, UW, Warszawa-Katowice, s. 41-74.

Kowalczyk S., 2005, Człowiek a społeczność. Zarys filozofii społecznej, KUL, Lublin.

Leśniak L., 2013, Idea podejścia LEADER, [w:] J. Puchała, M. Kowalska (red.), Rola i znaczenie Lokalnych Grup Działania w rozwoju obszarów wiejskich w Polsce, Wydawnictwo Adam Marszałek, Toruń, s. 9-16

Leźnicki M., 2011, Jakość życia jako przedmiot badań naukowych i refleksji, [w:] W. Tyburski (red.), Zasady kształtowania postaw sprzyjajqcych wdrażaniu zrównoważonego rozwoju, Uniwersytet Mikołaja Kopernika, Toruń, s. 224-231.

Łuszczyk M., 2013, Pomiar jakości życia w skali międzynarodowej, Uniwersytet Ekonomiczny w Krakowie, Kraków.

Mularska M., 2008, Czy można zmienić wieś bez udziału jej mieszkańców? O znaczeniu podmiotowości dla koncepcji zrównoważonego rozwoju, [w:] H. Podedworna, P. Ruszkowski (red.), Spoteczne aspekty zrównoważonego rozwoju wsi w Polsce. Partycypacja lokalna i kapitał społeczny, Wydawnictwo Naukowe SCHOLAR, Warszawa, s. 220-232.

Nurzyńska I., 2014, Nowe koncepcje i instrumenty polityki regionalnej w UE a rozwój obszarów wiejskich w Polsce, Wieś i Rolnictwo, 4 (165), s. 27-43.

Parysek J.J., 2001, Podstawy gospodarki lokalnej, Uniwersytet Adama Mickiewicza, Poznań.

Pawłowski A., 2007, Bariery we wdrażaniu rozwoju zrównoważonego - spojrzenie ekofilozofa, Problemy Ekorozwoju, 2, 1, s. 59-65.

van Praag B.M.S., van Herwaarden F.G., Kapteyn A.J., 1979, The definition and measurement of social references spaces, The Netherlands Journal of Sociology: Sociologia neerlandica, 15, s. 13-25.

Puchnarewicz E., 2013, Krajobraz kulturowy wsi jako atrakcja turystyczna, [w:] A. Dudek (red.), Szczęśliwi i biedni. Wieś i rolnictwo wobec współczesnych wyzwań rozwojowych. Księga jubileuszowa dla uczczenia dorobku prof. Janusza Gudowskiego, Uniwersytet Warszawski, Warszawa, s. 243-250. 
Rokicka E., 2013, Jakość życia - konteksty, koncepcje, interpretacje, [w:] J. Grotowska, E. Rokicka (red.), Nowy Ład? Dynamika struktur społecznych we współczesnych społeczeństwach, Księga pamiq̨tkowa poświęcona Profesor Wielisławie Warzywodzie-Kruszyńskiej z okazji 45-lecia pracy naukowej i dydaktycznej, Uniwersytet Łódzki, Łódź, s. 159-177.

Sztompka P., 2005, Socjologia zmian społecznych, Wydawnictwo Znak, Kraków.

Trzepacz P. (red.), 2012, Zrównoważony rozwój - wyzwania globalne. Podręcznik dla uczestników studiów doktoranckich, Instytut Geografii i Gospodarki Przestrzennej UJ, Kraków.

Tyburski W., 2011, Wprowadzenie, [w:] W. Tyburski (red.), Zasady kształtowania postaw sprzyjajqcych wdrażaniu zrównoważonego rozwoju, Uniwersytet Mikołaja Kopernika, Toruń, s. 7-32.

Adamski T., Dzwonkowska K., Gorlach K., Pilichowski A., Starosta P., 2007, Wiedza w rozwoju zrównoważonym wsi. Programy - Projekty - Działania, Uniwersytet Jagielloński, Kraków.

Zadrożniak M., 2015a, Środowisko przyrodnicze jako czynnik determinujqcy poprawę jakości życia mieszkańców obszarów wiejskich w kontekście koncepcji zrównoważonego rozwoju, [w:] B. Bartniczak, K. Trzeciak (red.) Aktualne trendy w zarzqdzaniu środowiskiem, Uniwersytet Ekonomiczny we Wrocławiu, Jelenia Góra, s. 211-218.

Zadrożniak M., 2015b, Wyrównywanie szans edukacyjnych w ramach polityki spójności jako kierunek poprawy jakości życia mieszkańców obszarów wiejskich, [w:] E. Pancer-Cybulska, E. Szostak (red.), Unia Europejska w 10 lat po największym rozszerzeniu, Prace Naukowe UE we Wrocławiu, 380, s. 334-341.

Zajda K., 2012, Przyczyny niedostosowania podejścia LEADER w gminach wiejskich woj. łódzkiego, Wieś i Rolnictwo, 2 (155), s. 69-81.

Zajda K., Kretek-Kamińska A., 2014, Wykorzystanie zasobów lokalnych grup działania, Uniwersytet Łódzki, Łódź.

Zarychta M., 2010, Przedsiębiorczość w zrównoważonym rozwoju obszarów wiejskich, [w:] M. Burchard-Dziubińska, A. Rzeńca (red.), Zrównoważony rozwój na poziomie lokalnym i regionalnym. Wyzwania dla miast i obszarów wiejskich, Uniwersytet Łódzki, Łódź, s. 199-219.

Zasady realizacji instrumentu Rozwój lokalny kierowany przez społeczność w Polsce, 2014, Ministerstwo Infrastruktury i Rozwoju, Warszawa.

\section{Summary}

The article attempts to analyze a new approach to rural development, in which one of the most important objectives is the improvement of residents' life quality. The implementation of this concept concentrated around local communities, which should be considered as conscious development entity. Regarding such approach, the notion of sustainable development clearly outlines basic principles and provides a definition of life quality, as well as resolves the issues of improvement, considering both the objective and subjective aspects. The most important conclusions from the above considerations regarding the practical application of CLLD in rural areas have been included through the results of this analysis. 